\title{
Perception on prevention of mother-to-child- transmission (PMTCT) of HIV among women of reproductive age group in Osogbo, Southwestern Nigeria
}

\author{
This article was published in the following Dove Press journal: \\ International Journal of Women's Health \\ 10 July 2013 \\ Number of times this article has been viewed
}

\author{
Al Olugbenga-Bello' \\ WO Adebimpe ${ }^{2}$ \\ FF Osundina ${ }^{3}$ \\ ST Abdulsalam ${ }^{3}$ \\ 'Department of Community Medicine, \\ Faculty of Clinical Sciences, College \\ of Health Sciences, Ladoke Akintola \\ University of Technology (LAUTECH), \\ Osogbo, Osun State, Nigeria; \\ ${ }^{2}$ Department of Community Medicine, \\ Osun State University, Osogbo, \\ Osun State, Nigera; ${ }^{3}$ Department \\ of Community Medicine, Ladoke \\ Akintola University of Technology \\ (LAUTECH) Teaching Hospital, \\ Ogbomoso, Oyo State, Nigeria
}

Correspondence: Al Olugbenga-Bello PO Box 1734 Osogbo,

Osun State, Nigeria

Tel +2348033839282

Email nike_bello@yahoo.com
Introduction: The fastest growing group of adults living with human immunodeficiency virus (HIV), is women. As more women contract the virus, the number of children infected in utero, intra-partum, and during breastfeeding has been growing. This study assessed the knowledge and attitude of women of child bearing age towards the prevention of mother-to-child-transmission (PMTCT) of HIV.

Materials and methods: This is a descriptive cross sectional survey of 420 women of the reproductive age group (15-49 years) selected using a multistage sampling technique. Data were obtained using interviewer-administered, pretested, semistructured questionnaires. The data were analyzed using the Statistical Package for Social Sciences (SPSS) software version 15.

Results: A high level of awareness about HIV/acquired immunodeficiency syndrome (AIDS) was observed among the respondents (99.8\%). The knowledge about MTCT and PMTCT of HIV was high, $92.1 \%$ and $91.4 \%$, respectively. However, a significant portion $(71.27 \%)$ of the study population had poor attitudes towards PMTCT of HIV.

Conclusion: Despite the high level of awareness of HIV/AIDS, and good knowledge about MTCT and PMTCT of HIV/AIDS among the respondents, the attitude towards PMTCT is poor. There is need for the involvement of the stakeholders in bridging the gap between knowledge and attitude of prevention of MTCT of HIV among women.

Keywords: HIV/AIDS, PMTCT, women, perception, knowledge, attitude

\section{Introduction}

The global human immunodeficiency virus (HIV) epidemic continues to expand, with an estimated five million people becoming infected each year. Over the decades, the epidemic once dominated by infected males has become progressively feminized, with over half of adults living with HIV being women. ${ }^{1}$ In sub-Saharan Africa, where about two-thirds of the global disease burden resides, $57 \%$ of adults living with HIV are women. As more women contract the virus, the number of children infected from their mothers has been growing. ${ }^{1}$ Every day there are nearly 1800 new HIV infections in children under 15 years of age, more than $90 \%$ occurring in the developing world. Most (about 90\%) of these infections are associated with mother-to-child-transmission (MTCT). In addition, every day 1400 children under 15 years of age die of an HIVrelated illness. ${ }^{2}$

MTCT accounts for the vast majority of the more than 700,000 estimated new HIV infections in children worldwide annually. ${ }^{3}$ These infection rates are disproportionately 
distributed geographically. While MTCT, in the context of antiretroviral prophylaxis is below 1\% in Europe and the USA, it exceeds $30 \%$ in many poorly resourced countries, with sub-Saharan Africa carrying the highest burden. ${ }^{4,5}$ Without intervention, HIV-infected mothers have a 35\% overall risk of transmitting HIV to their child during pregnancy, delivery, and breastfeeding. ${ }^{6}$ However, an effective prevention of MTCT can occur when HIV testing and other preventive interventions form part of comprehensive maternal and child health programmes. ${ }^{3}$ HIV prevalence among antenatal clients in Nigeria was $4.6 \%$ as at November 2011, while the number of pregnant women who received antiretroviral drugs (ARVs) for PMTCT was 32\%, while estimated number of HIV exposed infants at risk of MTCT annually was 85,450. ${ }^{7}$

The pandemic has reversed the gains in child survival made in many of the worst affected countries and has dramatically reduced average life expectancy in those countries. ${ }^{8}$ Thus prevention of MTCT (PMTCT) of an HIV infection is a politically and scientifically accepted approach to reduce the impact of HIV, especially on children. ${ }^{9}$ Clinical trials have demonstrated that ARV prophylaxis, when administered to mothers and their newborn babies, can reduce the risk of MTCT by approximately $75 \%{ }^{3}$ The Nigerian national goals for PMTCT, as stated in the 2005 National Policy on HIV/ AIDS, were to reduce MTCT by $50 \%$ by 2010 , and to increase access to quality, confidential counseling and testing services by $50 \%$ that same year. ${ }^{10}$ This seems to be in consonance with the United Nations General Assembly Special Session (UNGASS) declaration in 2001. ${ }^{11}$

The UN declaration established specific goals of reduction of the proportion of infants infected with HIV: reduced $20 \%$ by 2005 , and reduced $50 \%$ by $2010 .{ }^{11}$ However, studies have shown that PMTCT services are low in sub-Saharan Africa, ${ }^{12}$ and where these services are available, they are grossly underused. ${ }^{13,14}$ PMTCT services uptake is still low in Nigeria, though most efforts are donor driven and are readily accessible in urban centers. ${ }^{7}$ This study aims to assess the knowledge and attitude of women in the reproductive age group, as regards PMTCT of HIV, thus guiding the concerned stake holders in responding decisively to issues on PMTCT of HIV/AIDS.

\section{Materials and methods}

This study was a descriptive cross sectional survey of women of reproductive age, (15 years-49 years) in Osogbo metropolis, Osun State in the south-western part of Nigeria. The study was carried out between October 2008 and March 2009. Osogbo has a population of approximately 950,000. ${ }^{15}$
Each of the two local governments making up the city has ten wards. Osogbo city was selected for this study because of its low HIV prevalence in comparison to the national average, and because of reported high average attendance at antenatal care clinics compared to the national average. ${ }^{7}$ The calculated minimum sample size of 380 was adjusted for nonresponse and a total of 420 respondents were recruited into the study using a multistage sampling technique.

The first stage involved the selection of eight wards randomly from the two local governments, (Osogbo and Olorunda) that constituted the Osogbo metropolis by balloting. All the streets in the selected wards were numbered and a simple random sampling technique was used to select two streets from each ward by balloting method in stage two. Samplings of all houses in the sixteen selected streets were done. All women within the age group 15 years-49 years who normally resided in the household were considered eligible for this study, and were interviewed. In houses where women were found, a brief introduction was performed and verbal consent was sought before the administration of questionnaires.

Data were collated via pretested, semistructured questionnaires which were interviewer administered. The questionnaire was translated to the local language and the researchers made efforts to ensure uniformity in the questions asked to avoid interobserver error. The questionnaire included sections on the sociodemographic data of the respondents, and knowledge and attitude towards the prevention of MTCT of HIV. Data were entered into a computer and analyzed using the Statistical Package for Social Sciences (SPSS) software version 15 (IBM, Corporation, Armonk, NY, USA). Composite attitude scores were computed for PMTCT-related attitude by scoring 1 for each correct answer and 0 for an incorrect answer. These scores were then summed up and divided by the total number of test items to arrive at an average attitude score per person. Association between sociodemographic characteristics and knowledge of PMTCT was examined by applying the Chisquare test with significance set at the 5\% level.

\section{Results}

Four hundred and twenty questionnaires were distributed. Table 1 shows the sociodemographic characteristics of the respondents, $233(55.5 \%)$ were within the age group 21-30 years, mean age of respondents was $26.9 \pm 7.4$ years. The majority, 212 (50.5\%) were students, 285 (67.9\%) were Christians, and 394 (93.8\%) were Yorubas. Many, $280(66.7 \%)$ had tertiary education, 191 (45.5\%) were single, and $252(60 \%)$ had never had a child. 
Table I Sociodemographic characteristics of respondents $(n=420)$

\begin{tabular}{ll}
\hline Characteristics & Frequency $\mathbf{n}$ (\%) \\
\hline Age group (years) & \\
I5-20 & $81(19.3)$ \\
2 I-30 & $233(55.5)$ \\
$3 \mid-40$ & $70(16.7)$ \\
$4 I-50$ & $36(8.6)$ \\
Occupation & \\
Civil servant & $75(17.9)$ \\
Trader & $76(18.1)$ \\
Artisan & $22(5.2)$ \\
Professional & $23(5.5)$ \\
Unemployed & $12(2.8)$ \\
Student & $212(50.5)$ \\
Religion & \\
Christianity & $285(67.9)$ \\
Islam & $134(31.9)$ \\
Traditional & $1(0.2)$ \\
Tribe & \\
Yoruba & $394(93.8)$ \\
Ibo & $18(4.3)$ \\
Hausa & $4(1.0)$ \\
Others & $4(1.0)$ \\
Level of education & \\
No formal education & $30(7.2)$ \\
Primary & $15(3.6)$ \\
Secondary & $95(22.6)$ \\
Tertiary & $280(66.7)$ \\
Marriage setting & \\
Monogamy & $165(39.3)$ \\
Polygamy & $4 I(9.7)$ \\
Single parent & $23(5.5)$ \\
Unmarried & $191(45.5)$ \\
Parity & \\
None 4 & $252(60.0)$ \\
>4 & $152(36.3)$ \\
\hline & $16.8)$ \\
\hline
\end{tabular}

Almost all the respondents, 419 (99.8\%), had heard about HIV/AIDS. The major source of information for 414 (98.6\%) of the respondents was electronic media (radio and TV), then doctors $(362,86.20 \%)$, teachers $(314,74.9 \%)$, relatives $(298$, $71.1 \%$ ), and partners, $282(67.1 \%)$, as shown in Table 2. Three hundred and eighty seven (92.1\%) believed a mother can infect her child with HIV, while 292 (69.5\%), 333 (79.3\%), 363 (86.4\%), and 239 (56.9\%) agreed that MTCT of HIV takes place in utero, during delivery, through breastfeeding, and through invasive tests, respectively. However, some respondents $(92,21.9 \%)$ believed that MTCT of HIV takes place via mosquito bite. As shown in Table 3, the majority of the respondents agreed that pregnant women should be screened for HIV, 394 (93.8\%), referred to institutions where they can be monitored if infected, 387 (92.1\%) and should not breastfeed her child if infected, 349 (83.1\%). As shown in Table 4, 384 (91.4\%) of the respondents believed that
Table 2 Respondents' knowledge about HIVIAIDS $(n=420)$

\begin{tabular}{ll}
\hline Variables & Frequency $\mathbf{n}$ (\%) \\
\hline Awareness of HIV/AIDS & $419(99.80)$ \\
Yes & $1(0.20)$ \\
No & \\
Sources of information about HIV/AIDS & $414(98.60)$ \\
Radio and TV & $362(86.20)$ \\
Newspapers and magazines & $345(82.10)$ \\
Friends & $298(71.10)$ \\
Relatives & $314(74.90)$ \\
Teachers & $358(85.20)$ \\
Doctors & $282(67.10)$ \\
Partners & \\
Knowledge of modes of transmission & $417(99.3)$ \\
Unprotected sex with an infected person & $417(99.3)$ \\
Blood transfusion with infected blood & $410(97.6)$ \\
Sharing of sharp objects & $22(5.2)$ \\
Casual contact such as hugging, handshakes & $48(11.2)$ \\
Sharing of towel, spoons, etc & $87(20.7)$ \\
Insect bites like mosquitoes & $384(91.4)$ \\
Infected mother to child & $27(6.4)$ \\
Sleeping in the same room with infected individual & $74(17.6)$ \\
Swimming pool and public toilet & \\
Knowledge about MTCT of HIV & $387(92.1)$ \\
A mother can infect her child with HIV & $292(69.5)$ \\
MTCT of HIV takes place in utero/pregnancy & $333(79.3)$ \\
Through labor/delivery & $363(86.4)$ \\
Through breast feeding & $92(21.9)$ \\
Through mosquito bite & $239(56.9)$ \\
Through invasive tests & \\
\hline Ab & \\
\hline
\end{tabular}

Abbreviations: AIDS, acquired immunodeficiency syndrome; MTCT, mother-tochild-transmission; HIV, human immunodeficiency virus.

the MTCT of HIV can be prevented. Some, 144 (34.3\%), however believed that termination of pregnancy could be a method of prevention.

Many of the respondents, 275 (71.27\%), had poor attitude towards PMTCT of HIV, while only $111(28.73 \%)$ had good attitude. A greater percentage, 273 (65.0\%), of the respondents had heard about voluntary confidential counseling and testing (VCCT) although as many as $147(35.0 \%)$ of the respondents had not heard about VCCT. One hundred and forty three (34\%) of the respondents were not aware of their HIV status, among the 277 (66.0\%) of the respondents that were aware of their HIV status, 211 (76.28\%), 48 (17.15\%), and $18(6.57 \%)$ were tested at clinics, schools, and at outreaches, respectively. Of the $277(66.0 \%), 22(7.90 \%)$ claimed they were positive, 146 (52.8\%) claimed they were negative, and 109 (39.3\%) were unwilling to disclose their status. Cost was not a major factor in preventing the respondents from being HIV tested as only two (1.27\%) of the nontested respondents indicated cost to be a deterrent to HIV testing.

Respondents with a lack of knowledge about VCCT as a deterrent to HIV testing were 45 (28.66\%), while 41 (26.10\%) 
Table 3 Attitude of women of reproductive age towards HIV and MTCT $(n=420)$

\begin{tabular}{llll}
\hline Variables & \multicolumn{3}{l}{ Number (percentage) } \\
\cline { 2 - 4 } & Disagree & Indifferent & Agree \\
\hline $\begin{array}{l}\text { Pregnant women should be } \\
\text { screened for HIV }\end{array}$ & $14(3.4)$ & $12(2.9)$ & $394(93.8)$ \\
$\begin{array}{l}\text { Referral of HIV positive } \\
\text { pregnant women to institutions } \\
\text { where they can be monitored }\end{array}$ & $21(5)$ & $12(2.9)$ & $387(92.1)$ \\
$\begin{array}{l}\text { Use of antiretroviral drugs } \\
\text { during pregnancy }\end{array}$ & $24(5.7)$ & $22(5.2)$ & $374(89.0)$ \\
$\begin{array}{l}\text { HIV infected pregnant women } \\
\text { must deliver with skilled }\end{array}$ & $28(7.4)$ & $25(6.0)$ & $364(86.7)$ \\
$\begin{array}{l}\text { personnel } \\
\text { HIV infected pregnant women } \\
\text { should not deliver at home or } \\
\text { at TBAs }\end{array}$ & $68(16.2)$ & $32(7.6)$ & $320(76.2)$ \\
$\begin{array}{l}\text { HIV infected woman may not } \\
\text { breastfeed her child if there } \\
\text { is risk of infection }\end{array}$ & $47(1 \mathrm{l} .2)$ & $24(5.7)$ & $349(83.1)$ \\
\hline
\end{tabular}

Abbreviations: MTCT, mother-to-child-transmission; HIV, human immunodeficiency virus; TBA, traditional birth attendance.

had not been tested because they were not aware of any VCCT center. Most of the respondents, 349 (83.10\%), would agree to VCCT, $36(8.60 \%)$ would not agree, while $35(8.30 \%)$ were not sure. Attitude was significantly associated with the knowledge of HIV status $(P=0.013)$. Most respondents without the knowledge of their current HIV status (63.6\%) had poor attitude towards PMTCT. There is significant association between knowledge of MTCT and marital status $(P=0.029)$.

Table 4 Respondents knowledge of PMTCT

\begin{tabular}{ll}
\hline Variable & Frequency $\mathbf{n}$ (\%) \\
\hline MTCT can be prevented & $384(91.4)$ \\
Yes & $36(8.6)$ \\
No & \\
Means of prevention & $144(34.3)$ \\
Termination of pregnancy & $131(31.2)$ \\
Avoidance of drug use & $154(36.7)$ \\
Avoidance of smoking & $306(72.9)$ \\
Abstinence from unprotected sex & $227(53.4)$ \\
Early cessation of breastfeeding & $377(89.8)$ \\
Faithfulness to one's sexual partner & $292(69.5)$ \\
Cesarean section delivery & $286(68.1)$ \\
Avoidance of invasive tests & $35(8.3)$ \\
Avoidance of hugging, kissing, shaking & \\
infected person & $59(14.0)$ \\
Use of herbs & $338(80.5)$ \\
Use of antiretroviral drugs & $385(91.7)$ \\
Health education & $402(95.7)$ \\
Transfusion only with screened blood & \\
and blood products & $215(51.0)$ \\
Vaccination and immunization &
\end{tabular}

Abbreviations: MTCT, mother-to-child-transmission; PMTCT, prevention of mother-to-child-transmission.
Occupation, religion and education are significantly associated with knowledge about PMTCT, with $P$-values of 0.020 , 0.000 and 0.001 , respectively, as shown in Table 5. Reported HIV status by the respondents was also associated with occupation, age, marriage setting, and parity with $P$-values of $0.002,0.000,0.000$, and 0.039 , respectively.

\section{Discussion}

Women within the age group 15-49 years make up the majority of HIV infected people in Sub-Saharan Africa. ${ }^{1}$ This age group were the target of this study. A few of the respondents $(0.2 \%)$ had never heard about HIV/AIDS. This result is in contrast to reports from some other studies in Nigeria, in which all the respondents were well aware of HIV/AIDS. ${ }^{16,17}$ The level of awareness in this study was however higher than that found in a related study in Iran, ${ }^{18}$ where an appreciable proportion of the respondents had never heard of HIV. Electronic media as the major source of information on HIV/ AIDS in this study, is in agreement with other studies..$^{16,19,20}$

Table 5 Association between sociodemographic data and knowledge about PMTCT

\begin{tabular}{|c|c|c|c|c|c|}
\hline \multirow[t]{2}{*}{ Variables } & \multicolumn{2}{|c|}{ Knowledge n (\%) } & \multirow[t]{2}{*}{$P$-value } & \multirow[t]{2}{*}{ df } & \multirow[t]{2}{*}{ Remarks } \\
\hline & Yes & No & & & \\
\hline \multicolumn{6}{|l|}{ Occupation } \\
\hline Civil servant & $69(18.0)$ & $2(8.0)$ & 0.020 & 5 & Significant \\
\hline Trader & $65(17.0)$ & $10(40.0)$ & & & \\
\hline Artisans & $18(4.7)$ & $3(12.0)$ & & & \\
\hline Professional & $23(6.0)$ & $0(0.0)$ & & & \\
\hline Unemployed & $10(2.6)$ & I (4.0) & & & \\
\hline Students & $198(51.7)$ & $9(36.0)$ & & & \\
\hline \multicolumn{6}{|l|}{ Religion } \\
\hline Christianity & $262(68.2)$ & $15(60.0)$ & 0.000 & 2 & Significant \\
\hline Islam & $122(31.8)$ & $10(40.0)$ & & & \\
\hline \multicolumn{6}{|c|}{ Level of education } \\
\hline No formal education & $9(2.5)$ & I (4.0) & 0.001 & 5 & Significant \\
\hline Primary school & $13(3.6)$ & $2(8.0)$ & & & \\
\hline Secondary school & $79(21.7)$ & $12(48.0)$ & & & \\
\hline Tertiary school & $264(72.3)$ & $10(40.0)$ & & & \\
\hline \multicolumn{6}{|l|}{ Marriage settings } \\
\hline Monogamy & $152(40.5)$ & II (44.0) & 0.878 & 3 & Not \\
\hline Polygamy & $29(7.7)$ & $2(8.0)$ & & & significant \\
\hline Single parent & $19(5.1)$ & $2(8.0)$ & & & \\
\hline Unmarried & $175(46.7)$ & $10(40.0)$ & & & \\
\hline \multicolumn{6}{|c|}{ Age group (years) } \\
\hline $15-20$ & $76(20.3)$ & $3(12.0)$ & 0.751 & 3 & Not \\
\hline $21-30$ & $209(55.9)$ & $16(64.0)$ & & & significant \\
\hline $31-40$ & $65(17.4)$ & $4(16.0)$ & & & \\
\hline $41-49$ & $24(6.4)$ & $2(8.0)$ & & & \\
\hline \multicolumn{6}{|l|}{ Parity } \\
\hline$\leq 4$ & $136(90.1)$ & $12(92.4)$ & 0.987 & 5 & Not \\
\hline$>4$ & $15(9.9)$ & I (7.7) & & & significant \\
\hline
\end{tabular}

Abbreviations: $\mathrm{df}$, degree of freedom; PMTCT, prevention of mother-to-childtransmission. 
This method of education should be encouraged as it has been observed that radio and television are readily accessible to most people. In addition, exposure to mass media communication on HIV and AIDS issues was significantly reported to be associated with reduced stigma and discrimination against people living with HIV/AIDs (PLWHAs). ${ }^{21}$ However, this source of information is vulnerable to misconception, ${ }^{22}$ and concerns about the comprehensiveness of messages being passed through this medium have been expressed. ${ }^{23}$

MTCT rates in the developed world have fallen to less than $2 \%$ in recent years, largely because of the availability and widespread use of effective ART protocols, elective Cesarean delivery, and avoidance of breastfeeding. ${ }^{24-26}$ One of the important contributors to perinatal HIV transmission is birth-canal exposure of the infant to HIV. In untreated mothers, Cesarean delivery is reported to offer MTCT risk reduction of $50 \%$ to $81 \%$ when compared with vaginal delivery. ${ }^{26}$ Cesarean delivery was identified by only $30.5 \%$ of our respondents as a means of prevention of MTCT of HIV. This is even higher than values obtained from studies in other parts of the country. ${ }^{16,17,27}$ This could be due to the belief of the average Nigerian woman that the pain of labor, which is associated with vaginal delivery, is the glory of motherhood, so the pain should be experienced by every mother. A deterrent factor could also be the cost of cesarean birth.

On average, about $15 \%$ of babies born to HIV-positive mothers will become infected through prolonged breastfeeding ( 24 months or more). This transmission risk is doubled if the mother becomes infected with the virus while breastfeeding. ${ }^{28}$ The majority of our respondents, unlike $24 \%$ of the respondents in a study done by Adeleke et al, ${ }^{17}$ agreed that a woman infected with HIV should not breastfeed her child. This is quite commendable in a typical African setting where so much cultural significance is attached to breastfeeding and a woman that refuses to breastfeed her child, regardless of the reason, may suffer significant stigmatization and discrimination. However, only $53.4 \%$ of our respondents knew that early cessation of breastfeeding prevents MTCT of HIV. ${ }^{29}$ This knowledge is important in a setting where breastfeeding has sociocultural attachment.

Less than half of our respondents were unaware of their HIV status with cost not stated as a deterrent to HIV testing by most of them, an indication that most of them were aware that HCT is free. An appreciable percentage of them also indicated that lack of knowledge about VCCT, and a lack of awareness of available centers for VCCT, were not the factors responsible. The question then is why have they not been tested? This could be due to the fear of being stigmatized, peradventure they test positive. The most important barrier to the use of the services was found to be fear of stigma and discrimination against HIV positive pregnant women. ${ }^{30,31}$ It is disheartening that even health workers have been implicated in the issue of stigmatization and discrimination. ${ }^{32}$ This may explain why more than one-third of the respondents who were aware of their status were unwilling to disclose it, despite our assurance of a high level of confidentiality.

Though the knowledge about PMTCT and voluntary counseling and testing (VCT) is quite high among the respondents, the majority have a bad attitude towards PMTCT. This is in contrast to a study done in Botswana, where having a high PMTCT knowledge score was a major factor associated with good attitude towards PMTCT. ${ }^{33}$ However, the attitude of respondents towards VCT can be said to be good, as the majority of them would agree to VCT. Sociocultural factors such as stigmatization of HIV-infected individuals have been found to be the major barrier toward widespread acceptance of VCT in Nigeria. ${ }^{34}$ In fact, the majority of antenatal attendees in a related study in Northeast-Nigeria implored greater involvement of their male partners and other significant family members during PMTCT counseling sessions, to guard against ejection, stigma, and discrimination if tested HIV positive. ${ }^{35}$

There is a significant association between religion and knowledge about prevention of MTCT of HIV/AIDS $(P<0.05)$ in which Christianity has the highest proportion (68.2\%) of respondents with good knowledge about PMTCT. This finding could be due to the fact that religious leaders are getting involved in campaigns against HIV infection. Studies have showed that religious organizations are recognized for playing an important role in preventing new infections in Uganda. ${ }^{36,37}$ Nearly all of its major religious institutions, both Islamic and Christian, have been actively engaged in the country's struggle with HIV/AIDS. ${ }^{36}$ Many non-governmental organizations do plenty of collaborative work with religious organizations in Nigeria, all in a bid to increase awareness towards MTCT and its prevention. Unfortunately however, many faith-based organizations see immoral behavior as being the cause of the HIV/AIDS epidemic and they therefore decline involvement in preventive and intervention programmes. ${ }^{15}$ It is also important to note that over three-quarters of our respondents that have tested for HIV were tested at the clinic, though the reason for testing was not the focus of this study.

\section{Conclusion and recommendations}

The awareness of HIV/AIDS and knowledge about MTCT and PMTCT of HIV was quite high among the respondents. 
A significant number of respondents however, had a poor attitude towards PMTCT of HIV. A wide gap exists between the knowledge and attitude of PMTCT of HIV/AIDS. Health promotional activities and behavioral change through effective communication routes should be promoted. This would take targeted health education messages beyond impacting knowledge. A need for all relevant stakeholders in HIV-care to scale up PMTCT services to all women of reproductive age irrespective of location would make the services accessible to all, and assist in PMTCT of HIV.

\section{Disclosure}

The authors report no conflicts of interest in this work.

\section{References}

1. WHO/UNICEF and UNAIDS. A guide on indicators for monitoring and reporting on the health sector response to HIV/AIDS. Geneva, WHO 2011. Available at http://www.who.int/hiv/data/tool2011/en. Accessed November 2, 2011.

2. World Health Organization. Call to Action: Towards an HIV-Free and AIDS-Free Generation. Prevention of Mother to Child Transmission (PMTCT) High Level Global Partners Forum, Abuja, Nigeria, December 3, 2005. http://www.who.int/hiv/mtct/pmtct_calltoaction. pdf. Accessed February 14, 2013.

3. Centre for Disease Control and Prevention, World Health Organization, PEPFAR (President's Emergency Plan for AIDS Relief). http://www. pepfar.gov/documents/organization/133035.pdf. Accessed March 25, 2012.

4. Lehman DA, Farquhar C. Biological mechanisms of vertical human immunodeficiency virus (HIV-1) transmission. Rev Med Virol. 2007; 17(6):381-403.

5. John GC, Nduati RW, Mbori-Ngacha DA, et al. Correlates of motherto-child human immunodeficiency virus type 1 (HIV-1) transmission: association with maternal plasma HIV-1 RNA load, genital HIV-1 DNA shedding, and breast infections. J Infect Dis. 2001;183(2):206-212.

6. UNICEF. Nutrition-HIV and Infant Feeding. Available at http://www. unicef.org/nutrition/index_24827.htm. Accessed June 6, 2013.

7. National Agency for the Control of AIDS (NACA). Fact Sheet: PMTCT in Nigeria, 2011 NACA 2011. Available at http://naca.gov.ng/content/ view/399/lang,en/. Accessed November 4, 2011.

8. Huang R, Fulginiti LE, Peterson WW. Investing in Hope: AIDS, life expectancy, and human capital accumulation. University of Nebraska - Lincoln. Jul 2003.

9. Connor EM, Sperling RS, Gelber R, et al. Reduction of maternal-infant transmission of human immunodeficiency virus type 1 with zidovudine treatment. New Engl J Med. 1994;331(18):1173-1180.

10. Federal Government of Nigeria. Guidelines on Prevention of motherto-child Transmission (PMTCT) of HIV in Nigeria. Federal Ministry of Health. 2005.

11. United Nations General Assembly. Final Declaration of Commitment on HIV/AIDS (A/s-26/L2). New York: United Nations General Assembly, 2001. Available at http://data.unaids.org/publications/irc-pub03/ aidsdeclaration_en.pdf. Accessed June 3, 2013.

12. Nguyen TA, Oosterhoff P, Ngoc YP, Wright P, Hardon A. Barriers to access prevention of mother-to-child transmission for HIV positive women in a well-resourced setting in Vietnam. AIDS Res Ther. 2008;5:7.

13. Coovadia HM. Access to voluntary counselling and testing for HIV in developing countries. Ann N Y Acad Sci. 2000;918:57-63.

14. Preble EA, Piwoz EG. Prevention of mother-to-child transmission of HIV in Asia: Practical guidance for programs. Washington, DC: The Linkage project; 2002.
15. National Population Commission (NPC) 2006. Nigeria demographic and health survey. Calverton Maryland. NPC and ORC Macro. $45-47$.

16. Abiodun MO, Ijaiya MA, Aboyeji PA. Awareness and knowledge of mother-to-child transmission of HIV among pregnant women. J Natl Med Assoc. 2007;99(7):758-763.

17. Adeleke SI, Mukhtar-Yola M, Gwarzo GD. Awareness and knowledge of mother-to-child transmission of HIV among mothers attending the paediatric HIV clinic, Kano, Nigeria. Ann Afr Med. 2009;8(4):210-214.

18. Tarahomi M, Yaghmai F, Asadi S, et al. Preventing other-to-child transmission of HIV/AIDS: Do Iranian pregnant mothers know about it? J Reprod Infertil. 2010;11(1):53-57.

19. Cutilli CC. Seeking health information: what sources do your patients use? Orthop Nurs. 2010;29(3):214-219.

20. Ike SO, Aniebue PN. HIV/AIDS perception and sexual behavior among Nigerian university students. Niger J Clin Pract. 2007;10(2): 105-110.

21. Fakolade R, Adebayo SB, Anyanti J, Ankomah A. The impact of exposure to mass media campaigns and social support on levels and trends of HIV-related stigma and discrimination in Nigeria: tools for enhancing effective HIV prevention programmes. J Biosoc Sci. 2010;42(3):395-407.

22. Lindegren ML, Hanson C, Miller K, Byers RH, Onorato I. Epidemiology of human immunodeficiency virus infection in adolescents, United States. Pediatr Infect Dis J. 1994;13:525-535.

23. Burgoyne AD, Drummond PD. Knowledge of HIV and AIDS in women in sub-Saharan Africa. Afr J Reprod Health. 2008;12(2): 14-31.

24. Fiscus SA, Adimora AA, Funk ML, et al. Trends in interventions to reduce perinatal human immunodeficiency virus type 1 in North Carolina. Pediatr Infect Dis J. 2002;21:664-668.

25. Mandelbrot L, Landreau-Mascaro A, Rekacewicz C, et al. LamivudineZidovudine combination for the prevention of maternal Infection transmission of HIV-1. JAMA. 2001;285(160):2083-2093.

26. Cooper ER, Charurat M, Mofenson L, et al. Combination antiretroviral strategies for the treatment of Pregnant HIV-1 infected women and prevention of perinatal HIV-1 transmission. J Acquir Immune Defic Syndr. 2002;29:484-494.

27. Ogaji DS, Ikpeme BM, Oyo-Ita AE, Omuemu VO, Etuk SJ, Ekabua JE. Awareness and acceptability of strategies for preventing mother to child transmission of HIV among antenatal clients in Calabar, Nigeria. Niger J Med. 2008;17(1):29-32.

28. Dunn DT, Newell ML, Ades AE, Peckham CS. Risk of HIV 1 transmission through breastfeeding. Lancet. 1992;340:585-588.

29. Iliff PJ, Piwoz EG, Tavengwa NV, et al. Early exclusive breastfeeding reduces the risk of postnatal HIV-1 transmission and increases HIV-free survival. Aids. 2005;19(7):699-708.

30. Rogers A, Meundi A, Amma A, et al. HIV-related knowledge, attitude, perceived benefits, and risks of HIV testing among pregnant women in rural southern India. AIDS Patient Care STDS. 2006;20(11): 803-811.

31. Ndinda C, Chimbwete C, McGrath N, Pool R. Community attitudes towards individuals living with HIV in rural KwaZulu-Natal, South Africa. AIDS Care. 2007;19:92-101.

32. Misiri HE, Tadesse E, Muula AS. Are public antenatal clinics in Blantyre, Malawi, ready to offer services for the prevention of vertical transmission of HIV? Afr J Reprod Health. 2004;8(2):64-70.

33. Creek T, Ntumy R, Mazhani L, et al. AIDS and behavior, factors associated with low early uptake of a national program to prevent mother to child transmission of HIV (PMTCT): Results of a survey of mothers and providers, Botswana, 2003. AIDS Behav. 2009;13(2): 356-364.

34. Okonkwo KC, Reich K, Alabi AI, Umeike N, Nachman SA. An evaluation of awareness: Attitudes and beliefs of pregnant Nigerian women toward voluntary counseling and testing for HIV. AIDS Patient Care STDs. 2007;21(4):252-260. 
35. Moses AE, Chama C, Udo SM, Omotora BA. Knowledge, attitude and practice of ante-natal attendees toward prevention of mother to child transmission (PMTCT) of HIV infection in a tertiary health facility, Northeast-Nigeria. East Afr J Public Health. 2009;6(2): $128-135$.
36. Marshall K, Keough L. Uganda: Conquering Slim - Uganda's war on HIV AIDS. In: Marshall K, Keough L, editors. Mind, Heart and Soul in the Fight Against Poverty. Washington DC: World Bank; 2004.

37. Green EC. Faith-Based Organizations: Contribution to HIV Prevention. Washington DC: The Synergy Project; 2003.

International Journal of Women's Health

\section{Publish your work in this journal}

The International Journal of Women's Health is an international, peerreviewed open-access journal publishing original research, reports, editorials, reviews and commentaries on all aspects of women's healthcare including gynecology, obstetrics, and breast cancer. The manuscript management system is completely online and includes a very quick and fair peer-review system, which is all easy to use. Visit http://www.dovepress.com/testimonials.php to read real quotes from published authors.

Submit your manuscript here: http://www.dovepress.com/international-journal-of-womens-health-journal 